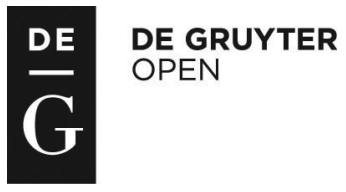

\title{
CHANGES IN MILK YIELD AND QUALITY DURING LACTATION IN POLISH RED AND WHITE-BACKED COWS INCLUDED IN THE GENETIC RESOURCES CONSERVATION PROGRAMME IN COMPARISON WITH THE SIMMENTAL BREED*
}

\author{
Zygmunt Litwińczuk $^{1 \bullet}$, Joanna Barłowska ${ }^{2}$, Alicja Matwijczuk ${ }^{1}$, Jan Słomiany ${ }^{3}$ \\ ${ }^{1}$ Department of Breeding and Protection of Genetic Resources of Cattle, \\ University of Life Sciences, Akademicka 13, 20-950 Lublin, Poland \\ ${ }^{2}$ Department of Commodity Science and Processing of Raw Animal Materials, \\ University of Life Sciences, Akademicka 13, 20-950 Lublin, Poland \\ ${ }^{3}$ Roztocze National Park, Plażowa 2, 22-470 Zwierzyniec, Poland \\ •Corresponding author: zygmunt.litwinczuk@up.lublin.pl
}

\begin{abstract}
Milk yield and quality was assessed in cows raised on low-input farms (traditional feeding), i.e. two breeds covered by genetic resources conservation (RP and BG) and the SM breed. The reference group was PHF HO cows from an intensive milk production system (PMR feeding). A total of 1,212 milk samples were collected from three periods of lactation: I (up to 120 days), II (121-200) and III (over 200). The milk was analysed for content of fat, protein, casein, lactose, dry matter, non-fat dry matter and the protein-to-fat ratio, coagulation time, heat stability and the percentage of fat globules in different size ranges. Fatty acid profile and cholesterol content were determined in a representative number of $\mathbf{1 8 0}$ milk samples. Daily yield in the native breeds in the third phase of lactation was 9.6 and $8.7 \mathrm{~kg}$, which was slightly over $55 \%$ of their yield in phase I, compared to $66 \%$ in the SM and $73.4 \%$ in the reference group (PHF HO). The increase in fat and protein (including casein) in the milk during lactation was much higher in the native breeds, so its energy value in phase III of lactation was $11 \%$ higher in the BG cows and $9 \%$ higher in RP, but only $4 \%$ higher in the SM with regard to phase I of lactation. The milk fat from the Polish Red cows had the highest proportion of PUFA in each phase of lactation, including CLA, and the highest PUFA/ SFA ratio. Over the course of lactation the percentage of large fat globules in the milk decreased, particularly in the native breeds $(\mathrm{P} \leq \mathbf{0 . 0 1})$, while in the SM the differences were much smaller and statistically insignificant. Lactation persistency in both native breeds raised in a low-input system was worse than in the SM, but the increase in basic components during lactation was markedly higher, while that of cholesterol was lower.
\end{abstract}

Key words: native breeds, dairy cattle, lactation persistency, milk quality

*This study was funded from statutory activity. 
One of the factors determining economic effects in milk production is lactation persistency in cows (Togashi and Lin, 2009). It is measured as the decrease in the level of milk production in successive months after peak yield, which is usually in the second month after calving. The dynamics of this indicator are determined by a number of factors, such as breed, diet, age, mammary gland disorders, frequency of milking, and the length of the lactation and dry periods (Bouallegue et al., 2014; Heins et al., 2012; Nor et al., 2014; Sawa et al., 2015; Topolski et al., 2008). Litwińczuk et al. (2015) report that the rate of the decrease in milk yield in successive thirds of the lactation period was slower in herds from intensive production (PMR diet); the reduction in daily yield in phase III of lactation (compared to phase I) was only $16 \%$, while fat content increased by $0.22 \mathrm{pp}$ (percentage points) and protein by $0.33 \mathrm{pp}$. On the farms with a traditional system the decrease in the daily milk yield was much greater, at over $35 \%$, with fat content increasing by $0.34 \mathrm{pp}$ and protein by as much as 0.81 pp. Jóźwik et al. (2012), comparing the chemical composition of milk on the 60th and 200th day of lactation, also found that in cows with average yield (about 7,000 1 of milk) the increase in protein and fat content was higher than in cows with yield of about 10,000 l of milk.

Native breeds are a highly valuable reservoir of genes, particularly when a return to the progenitor is not possible, as in the case of cattle. Breeders value local breeds for their disease resistance, longevity and high conception rate. The basic form of conservation of farm animals is in situ protection, owing to which they can be exploited in the regions where they were produced and valuable raw materials and products can be obtained from them. This pertains especially to brand-name products which are a reflection of local culinary traditions, including dairy products, and in particular cheeses (Litwińczuk, 2011). One of the best strategies for guaranteeing that native breeds continue to be exploited is promotion of products derived from them that are recognized on the market and can be sold at a higher price. A good example is Parmigiano Reggiano cheese, produced in northern Italy exclusively from the milk of cows of the Reggiana breed (Zannoni, 2010).

Native breeds of animals, which are characteristic of a given region or country, are ideally adapted to local environmental conditions. Moreover, local breeds are often a part of various regional traditions, and play an important role in the preservation of cultural heritage (Hiemstra et al., 2010; Litwińczuk, 2011). Milk obtained from cows of local breeds usually has higher nutritional value (with more healthpromoting components, such as whey proteins or CLA) and is more suitable for processing, particularly for production of ripened cheeses (Grega et al., 2005; Hiemstra et al., 2010; Litwińczuk et al., 2012).

Native breeds of cattle are usually raised on low-input farms (often termed traditional or extensive), usually characterized by low stocking density, a large proportion of permanent grassland, a low level of mineral fertilizer and low consumption of concentrate feed (Litwińczuk, 2011).

The aim of the study was to analyse changes during the course of lactation in daily yield and quality of milk obtained from the two oldest Polish native breeds of cow (Polish Red and White-Backed) and Simmental cows kept on small farms in a low-input system. The reference group consisted of Polish Black-and-White Holstein-Friesian cows kept in intensive systems (PMR feeding). 


\section{Material and methods}

The study included 70 White-Backed cows (BG), 82 Polish Red cows (RP) and 79 Simmental cows (SM) from 13 low-input farms (with traditional feeding) in Eastern Poland. The reference group consisted of 70 Polish Black-and-White HolsteinFriesian cows (PHF HO) kept on one farm with intensive milk production technology. All cow barns were subject to use value assessment for dairy cattle and met the requirements for milk production specified by Commission Regulation (EC) No. 1662/2006 of 6 November 2006, amending Regulation (EC) No. 853/2004 of the European Parliament and of the Council laying down specific hygiene rules for food of animal origin.

On the low-input farms (with cows of native breeds, i.e. BG and RP, as well as $\mathrm{SM}$ ), feeding was based on on-farm fodder. In the spring/summer the cows' diet consisted mainly of pasture forage (ca. $50 \mathrm{~kg}$ ) and hay $(2-3 \mathrm{~kg})$ supplemented with on-farm concentrate feed (1-2 kg). In the autumn/winter season the cows were fed haylage (ca. $15 \mathrm{~kg}$ ) and hay (3-4 kg), and on some of the farms (7 farms) they also received maize silage (ca. $10 \mathrm{~kg}$ ). The feed ration was supplemented with concentrate feed (1-2 kg). The PHF HO cows were fed year round in an intensive system (PMR). The PMR ration consisted mainly of maize silage, haylage, straw, post-extraction meal (soy, rapeseed) and grain meal. Daily feed rations were calculated for a cow with milk yield of 24.51 . For each subsequent 2.51 of milk the cows received $1 \mathrm{~kg}$ complete feed with $20 \mathrm{~g} / 100 \mathrm{~g}$ protein in the feed station.

A combined 1,212 milk samples were collected from the cows, including 331 from the BG breed, 324 from RP, 314 from SM and 243 from PHF HO. Samples were collected from three phases of lactation: I (up to 120 days) - 449 samples, II (days 121-200) - 279 samples, and III (over 200 days) - 484 samples. Samples were collected individually from each cow from milk obtained from a complete milking procedure (AT4 method), in two seasons (spring/summer and autumn/winter) for three years. Milk samples for analysis were taken not earlier than in 30th day after calving, and no later than 330th day. Samples from cows with diseased udders were eliminated. The milk was transported in thermal bags with freezer packs to the laboratory of the Department of Commodity Science and Processing of Raw Animal Materials, University of Life Sciences in Lublin (AOAC, 2000 b). In order to eliminate milk samples from cows with diseased udders (over 400,000 SCC/ml), the somatic cell count (SCC) was determined using a Somacount 150 apparatus manufactured by Bentley Instruments Inc., Chaska, MN, USA.

Content of fat, protein and lactose was determined in each milk sample with an Infrared Milk Analyzer by Bentley Instruments Inc. (these data were used to calculate content of dry matter and non-fat dry matter and the protein-to-fat ratio). Casein content was determined by the AOAC method (2000 a), coagulation time by Schern's method (a $250 \mu$ l volume of rennet solution (Fromase®2200 IMCU/g Granulate, DSM Food Specialities, France) at a concentration of $0.66 \mathrm{~g} / 100 \mathrm{ml}(\mathrm{w} / \mathrm{v})$ was added to $25 \mathrm{ml}$ of milk heated to $35^{\circ} \mathrm{C}$ in a water bath and maintained at that temperature $\left(35^{\circ} \mathrm{C} \pm 0.5^{\circ} \mathrm{C}\right)$, and the sample was observed until the moment when the first casein floccules formed), and heat stability at $140^{\circ} \mathrm{C}$ in a TEWES-BIS oil bath 
using White and Davies' method (White and Davies, 1966). The percentage of fat globules in different size ranges was determined, i.e. $<6 \mu \mathrm{m}, 6-10 \mu \mathrm{m}$ and $>10 \mu \mathrm{m}$ (under a microscope at $1,000 \times$ magnification on slides stained with Sudan III, in three fields of view).

The energy value of $1 \mathrm{~kg}$ of milk was calculated as well, using gross physiological energy factors (17.1 kJ per g protein; $38.7 \mathrm{~kJ}$ per g fat; $17.2 \mathrm{~kJ}$ per g lactose) according to Rubner (Pijanowski et al., 2000), using the following formula:

$1 \mathrm{~kg}$ milk $(\mathrm{kJ})=\{[\mathrm{g}$ protein $\times 10](\mathrm{g}) \times$ density $(\mathrm{g} / \mathrm{ml}) \times 17.1(\mathrm{~kJ})\}+\{[\mathrm{g}$ fat $\times 10)]$ $(\mathrm{g}) \times$ density $(\mathrm{g} / \mathrm{ml}) \times 38.7(\mathrm{~kJ})\}+\{[$ g lactose $\times 10](\mathrm{g}) \times$ density $(\mathrm{g} / \mathrm{ml}) \times 17.2(\mathrm{~kJ})\}$

Fatty acid profile and cholesterol content were determined in a representative number of 180 milk samples. Fatty acid content was determined following fat extraction according to AOAC Method 905.02 (2000 c). The fatty acids contained in the isolated fat were converted to fatty acid methyl esters (FAME) according to PN-EN ISO 5509 (2001). FAME separation was carried out by gas chromatography (GC) according to PN-EN ISO 5508 (1996) using a Varian CG 3900 apparatus (Walnut Creek, CA USA) equipped with a flame ionization detector (FID). A CP 7420 capillary column (Agilent Technologies, USA) was used, $100 \mathrm{~m}$ in length with an internal diameter of $0.25 \mathrm{~mm}$ and film thickness of $0.25 \mu \mathrm{m}$. The analysis was carried out in increasing temperature conditions; the initial temperature of the oven was $50^{\circ} \mathrm{C}$, and the final temperature was $260^{\circ} \mathrm{C}$. The temperature of the injector and the detector was $270^{\circ} \mathrm{C}$, the carrier gas (hydrogen) flow rate $2 \mathrm{ml} / \mathrm{min}$, the size of the injected samples $1 \mu 1$, and the split ratio 1:50. Fatty acids were identified by comparing the retention times for FAME present in the sample with retention times for Sigma FAME standards (Lipid Standard).

The results obtained were expressed as the percentage share of each FA among all the methyl esters according to PN-EN ISO 5508 (1996), using Star GC Workstation software v. 5.5 .

The following groups were distinguished in the fatty acid profile:

- saturated fatty acids (SFA), including short- and medium-chain (SCFA+MCFA) from C4:0 to C12:0 and long-chain fatty acids (LCFA) from C13:0 to C22:0

- unsaturated fatty acids, including monounsaturated fatty acids (MUFA) and polyunsaturated fatty acids (PUFA).

The ratios of these acids were calculated as well, i.e. SFA/UFA, MUFA/SFA and PUFA/SFA.

Cholesterol content was determined according to a method developed by the National Research Institute of Animal Production in Balice (with our own modifications). The procedure for determination of cholesterol content in milk was as follows: $35 \mathrm{ml}$ of a mixture of chloroform and methanol was added to $5 \mathrm{ml}$ of milk. After centrifugation, $4 \mathrm{ml}$ of the mixture was collected from the lower layer to $\mathrm{Su}-$ pelco vials and subjected to evaporation under a stream of nitrogen. Evaporation residue was saponified in closed vials with $3 \mathrm{ml}$ of $0.5 \mathrm{~N} \mathrm{NaOH}$ at $80^{\circ} \mathrm{C}$. After cooling, $3 \mathrm{ml}$ of hexane was added and extracted in sealed vials. Then, $1 \mathrm{ml}$ of hexane layer was sampled and evaporated at $65^{\circ} \mathrm{C}$ in a stream of nitrogen. $4 \mathrm{ml}$ of glacial 
acetic acid was added to the residue. Subsequently, $3.5 \mathrm{ml}$ was taken and added to $2.5 \mathrm{ml}$ of colour solution, and the mixture was stirred and cooled. The measurements were performed in a spectrophotometer Carry 300 (Varian) at $570 \mathrm{~nm}$ (Litwińczuk et al., 2014).

Data pertaining to the daily milk yield of the cows and the phase (day) of lactation were obtained from documentation conducted by the Polish Federation of Cattle Breeders and Dairy Farmers.

The results were analysed statistically in Statistica software (StatSoft Inc.), using one- and two-way analysis of variance (with interaction), with the breed of cow and phase of lactation as the sources of variation. Significance of differences between means for each factor were determined by Tukey's test. Changes in daily yield and milk parameters between phases I and III of lactation were calculated according to the following formula:

$$
\frac{\text { III phase of lactation }}{\text { I phase of lactation }} \times 100 \%
$$

\section{Results}

The data presented in Table 1 show that in all breeds of cow evaluated daily milk yield decreased significantly in successive phases of lactation. The scale of these changes, however, was strongly varied. In the third phase of lactation the daily milk yield of the cows of the two native breeds, RP and BG, was $9.6 \mathrm{~kg}$ and $8.7 \mathrm{~kg}$, respectively, which was only $55.8 \%$ of their yield in the first phase. Much more favourable lactation persistency $(66 \%)$ was noted for the cows of the SM breed, and the most favourable $(73.4 \%)$ for the cows in the reference group, i.e. PHF HO raised in an intensive farming system.

Analysis of the changes in the composition of the milk in successive phases of lactation (Table 1) shows that the main changes were an increase in protein content (by $21-31 \%$ ) and to a lesser extent fat content (by $4-12 \%$ ), and a decrease in lactose (by $2-6 \%$ ). The increase in the content of basic components, including casein, was markedly higher in the milk of the native breeds, so that the energy value of the milk obtained in phase III of lactation was $11 \%$ higher in the milk of the BG cows and $9 \%$ higher in RP, but only 4\% higher in the SM and 6\% higher in PHF HO.

The fat of the milk of the RP cows had the highest percentage of PUFA (3.58-4.13\%), including CLA (0.56-0.96\%), and the highest PUFA/SFA ratio $(0.052-0.061)$ in each phase of lactation. The lowest percentage of these acids was stated in milk of PHF HO cows: $2.19-3.79 \%, 0.24-0.30 \%$ and $0.033-0.035$, respectively (Table 2). The phase of lactation generally had no significant influence on the fatty acid profile of the milk, but several significant interactions (breed $\times$ phase of lactation) were found, e.g. for the percentage of UFA and MUFA and for the SFA/ UFA and MUFA/SFA ratios $(\mathrm{P} \leq 0.05)$, which were probably the result of the significant differences shown between phases of lactation, but only in the SM breed (Table 2). 


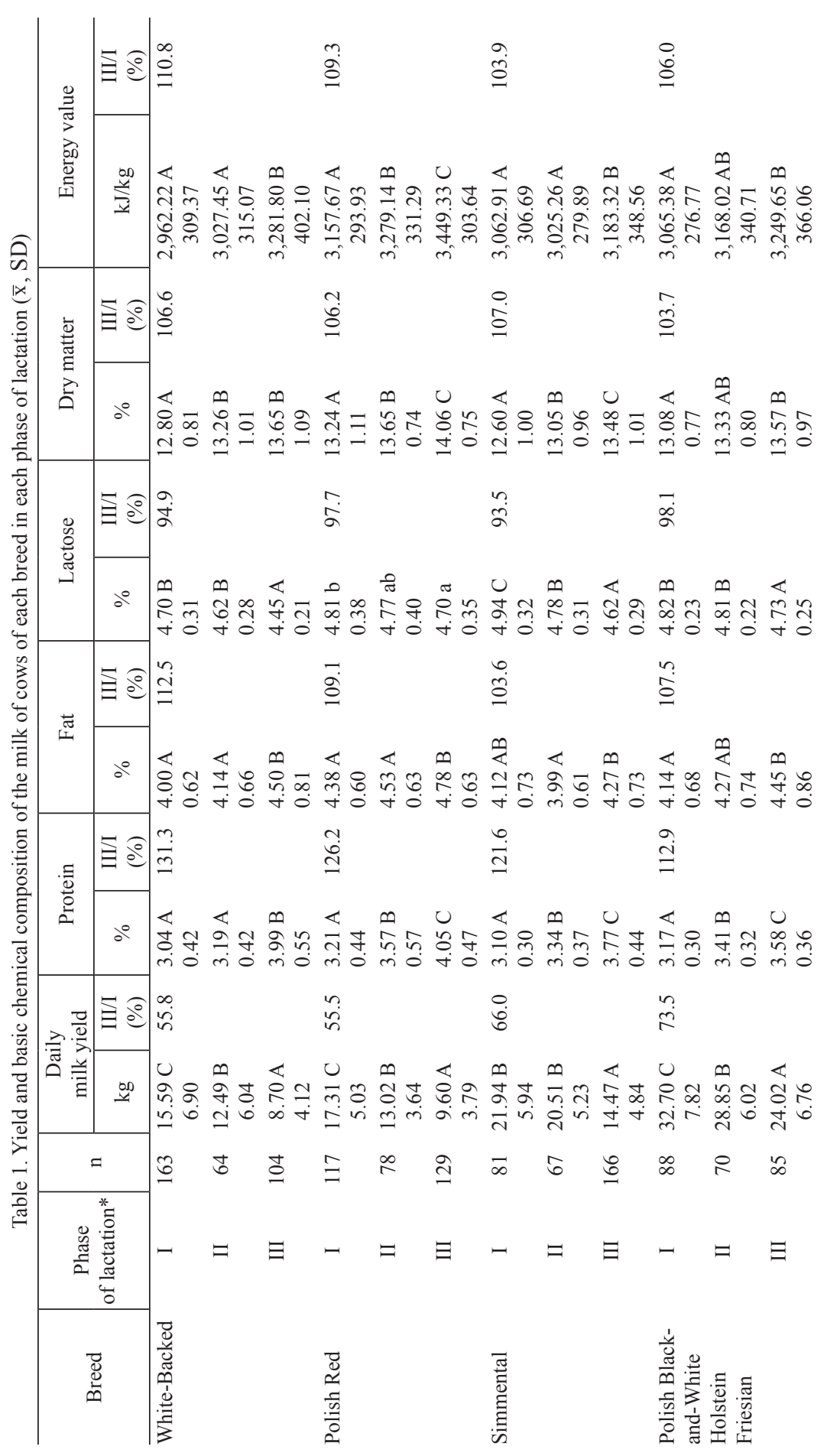




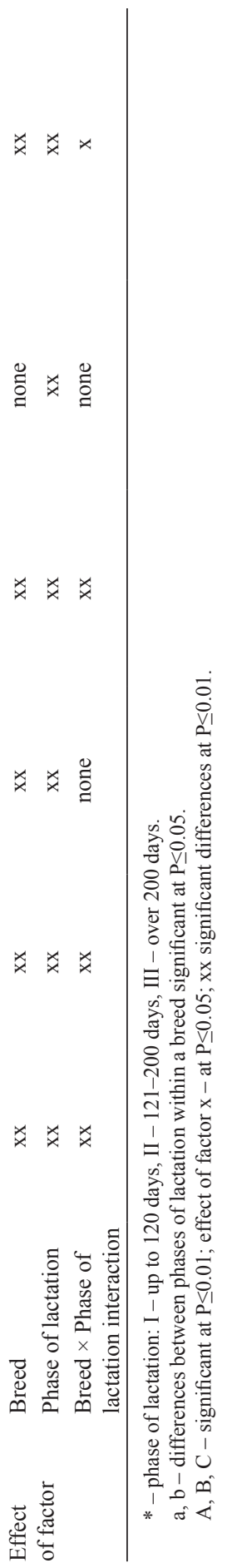




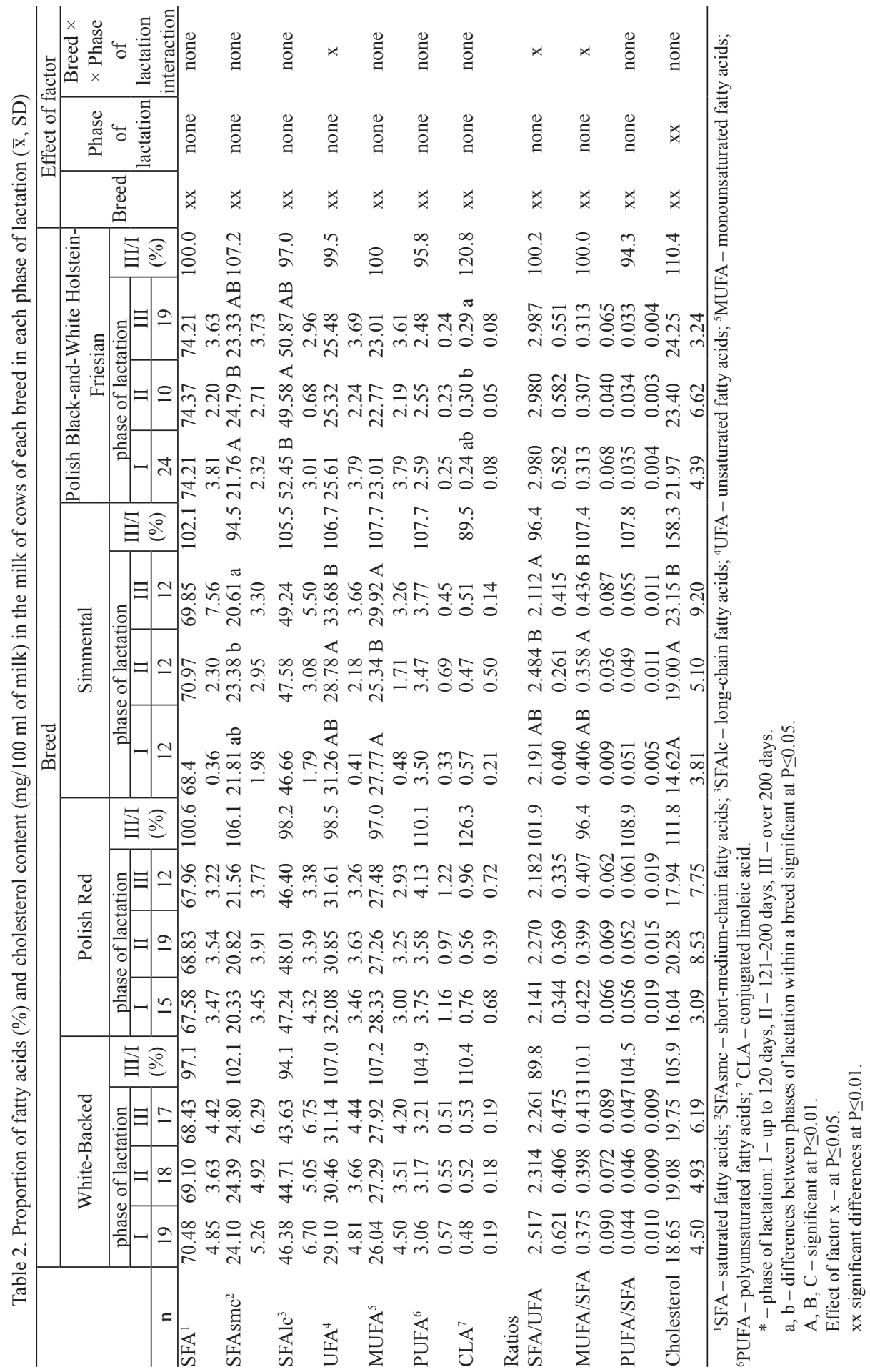




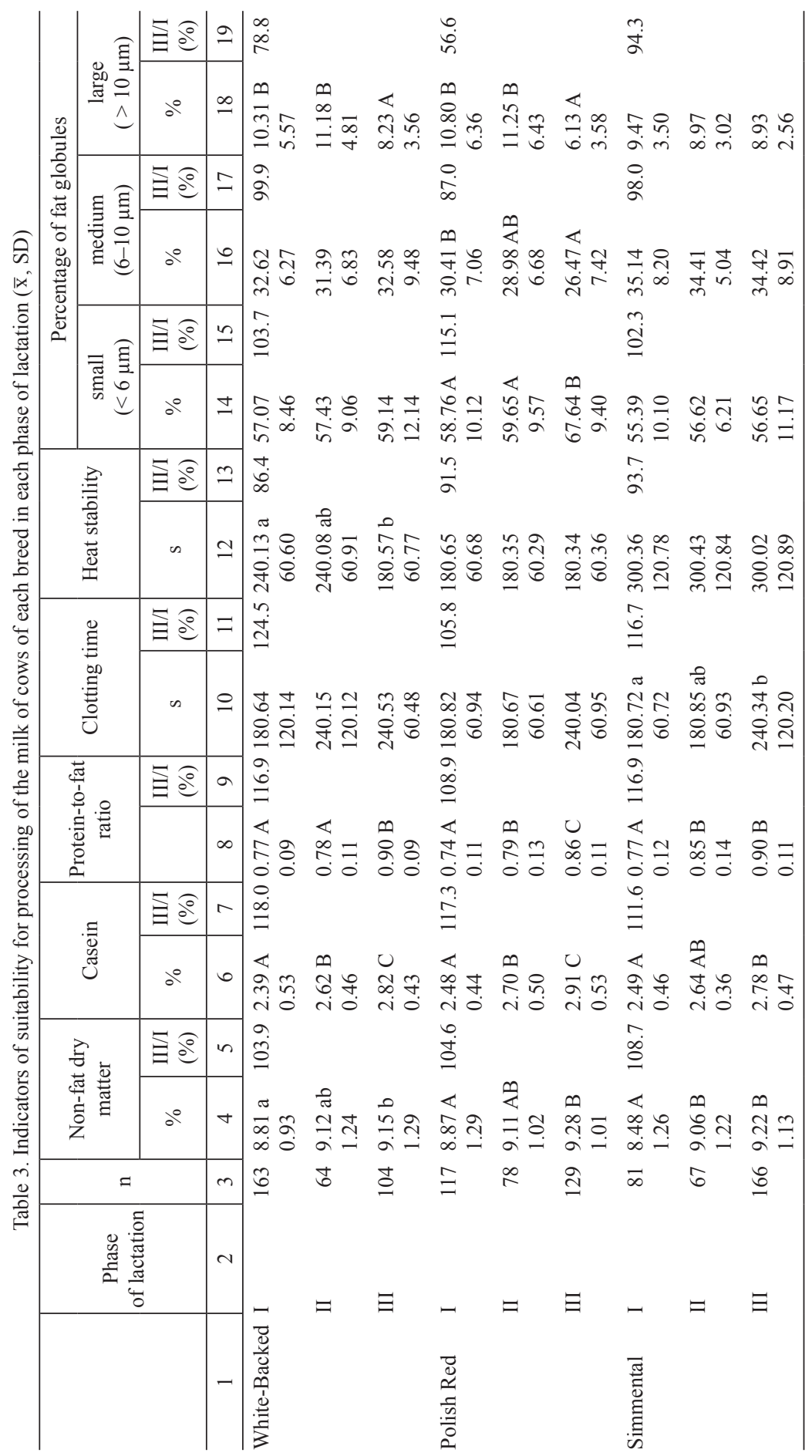




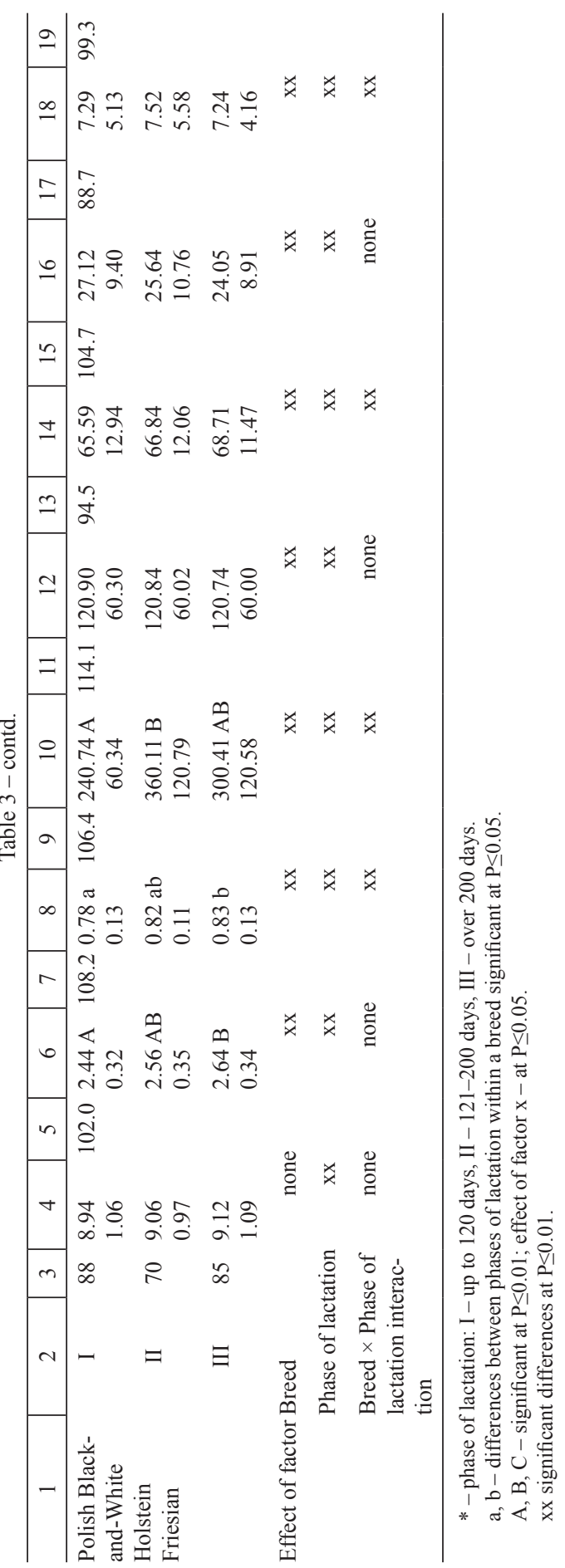


The phase of lactation was found to influence cholesterol content in the milk (Table 2). The content of this sterol increased over the course of lactation, but the increase was slowest in the milk of the native breeds, reaching a level of $17.94 \mathrm{mg} / 100$ $\mathrm{ml}$ in the RP cows and $19.75 \mathrm{mg} / 100 \mathrm{ml}$ in the BG cows in the third phase of lactation. Cholesterol content was $23.15 \mathrm{mg} / 100 \mathrm{ml}$ in the $\mathrm{SM}$ breed during this period and $24.25 \mathrm{mg} / 100 \mathrm{ml}$ in the reference group (PHF HO). Significant differences between phases of lactation were only noted for the Simmental breed $(\mathrm{P} \leq 0.01)$.

Over the course of lactation there was an increase $(\mathrm{P} \leq 0.01)$ in the content of nonfat dry matter from $8.75 \%$ to $9.22 \%$ (average for three analysed breeds, i.e. RP, BG and $\mathrm{SM}$ ) and casein (from $2.44 \%$ to $2.83 \%$ ) and in the protein-to-fat ratio (from 0.76 to 0.88 ) (Table 3). The greatest increase in casein content was noted in the milk of the cows from the two native breeds, BG (by 18\%) and RP (by 17\%). This component increased by $11 \%$ in the milk of the SM cows, and by only $8 \%$ in the PHF HO cows (from an intensive farming system).

The milk produced in a low-input system had a significantly shorter coagulation time (average $240 \mathrm{~s}$ ) than the milk from the reference group (PHF HO) $-300 \mathrm{~s}$. The phase of lactation was found to have a significant $(\mathrm{P} \leq 0.01)$ effect on coagulation time, which increased over the course of lactation (Table 3 ).

The lowest resistance to heat treatment was characteristic for milk of PHF HO cows (average $120 \mathrm{~s}$ ), and the highest - SM (average $300 \mathrm{~s}$ ). Lactation phase had no effect on the heat stability of milk (Table 3).

Milk fat dispersion also changed over the course of lactation, as the percentage of large fat globules decreased $(\mathrm{P} \leq 0.01)$ from $10.17 \%$ to $8.06 \%$, while the percentage of small globules increased, from $57.24 \%$ to $60.85 \%$ (average for three analysed breeds, i.e. RP, BG and SM). The greatest changes were noted in the milk of the cows of the two native breeds, RP and BG, while in the SM the differences were much smaller and statistically insignificant (Table 3). It should be emphasized that in the reference group, i.e. the PHF HO cows raised in an intensive system, the greatest fat dispersion was noted, indicated by the low percentage of large fat globules in successive phases of lactation (7.24-7.52\%).

\section{Discussion}

The inferior lactation persistency shown in the cows of the two native breeds (RP and BG) has been confirmed in other studies. Sabbioni et al. (2012) analysed this problem in cows of the Italian local breed Bianca Val Padana and in the high-production breed Italian Friesian, raised in two different types of production system, i.e. intensive (free-stall barns and PMR feeding) and traditional (tie-stall barns and traditional feeding). They showed that the Bianca Val Padana cows had inferior lactation persistency than the Italian Friesian cows. They state that this breed is better adapted to traditional farming conditions, as in intensive milk production systems their lactation curves are atypical, with the production peak occurring in the first week of lactation, followed by a sharp decline in milk production in the next two weeks, which 
continues, though at a slower rate, until the end of lactation. It should be emphasized that in phase III of lactation the mean yield of the cows of the Simmental breed (classified as a dual-purpose breed) was $14.5 \mathrm{~kg}$ of milk, which was $50-60 \%$ higher than in the cows of the two native breeds, also considered dual-purpose. However, in a study by Cilek et al. (2008) conducted on Simmental cows (1,367 305-day lactations in the years 1992-2002), lactation persistency was only $45.5 \%$, which should probably be linked to the very poor diet of these animals. Topolski et al. (2008) report that the size of the decrease in milk production during lactation was linked to the production level of the cows. In cows with higher productivity (over 7,100 kg of milk) the decrease in yield in the first months after the peak of lactation was smallest, while in cows with lower productivity (less than $5,700 \mathrm{~kg}$ of milk) the decrease was more rapid.

The changes observed in the composition of the milk of the cows of the local breeds raised on low-input farms and the Holstein-Friesians raised in an intensive system are confirmed in a study by Litwińczuk et al. (2015). Comparing changes in the chemical composition of the milk of cows housed in barns in intensive and traditional production systems, they also found the greatest increase in protein content: $9.5 \%$ in the intensive system, i.e. from $3.47 \%$ in phase I of lactation to $3.80 \%$ in phase III, and as much as $26 \%$ (from 3.11 to $3.92 \%$ ). Ikonen et al. (2004), evaluating the effect of the phase of lactation on milk yield and composition, showed that the lowest protein content, including that of casein, was at the peak of lactation (between days 31 and 60). The lowest fat content in the milk was observed between days 91 and 120 of lactation. In subsequent phases of lactation the content of both of these components successively increased, with a greater increase in fat content.

The highest proportion of PUFA, including CLA, in the milk fat of the Polish Red breed is confirmed by a previous study by the authors (Litwińczuk et al., 2012), and can probably be linked to the different phylogenetic origin of this breed (Konopiński, 1949; Pruski, 1975). Secchiari et al. (2003), comparing the proportions of selected fatty acids in the milk fat of the Italian Friesian and Reggiana breeds, found no differences between them in the average proportion of long-chain fatty acids. However, they showed that in the first period of lactation, when cows often have a negative energy balance, the milk fat contained more 18-carbon fatty acids, and less C14:0, C14:1 and C16:0. Content of the acid C18:2 $c 9, t 11$ successively increased over the course of lactation, from 0.59 in the first month to $0.89 \mathrm{~g} / 100 \mathrm{~g}$ of extracted fat in the seventh. Sobotka et al. (2014), evaluating changes in the fatty acid profile of milk fat during lactation in Holstein-Friesians, Jerseys and crosses of these breeds, found that content of SCFA decreased as lactation progressed. In the LCFA group, content of C12:0 and C18:0 was highest on the 160th day of lactation, while content of C14:0 iso and $\mathrm{C} 16: 0$ was higher in the final phase.

The increase shown in cholesterol content in the milk of the cows over the course of lactation is confirmed in a study by Strzałkowska et al. (2010), in which it increased from $15.6 \mathrm{mg} / \mathrm{dL}$ in phase I of lactation (days 6-60) to $16.9 \mathrm{mg} / \mathrm{dL}$ in phase III (days 211-305) in the milk of the cows fed in a PMR system. Litwińczuk et al. (2015) demonstrated higher cholesterol content in milk obtained from intensive pro- 
duction technology, and at the same time more uniform content throughout lactation in comparison with the milk of cows from traditional production systems.

Significant parameters determining the suitability of milk for processing include the protein-to-fat ratio, content of non-fat dry matter, and especially casein content, as casein content in milk influences the final compactness of the curd. According to Amenu and Deeth (2007), casein is responsible for the formation of the initial structure of the curd and its capacity to retain water and fat. It should be emphasized that the greatest increase in casein content was demonstrated in the milk of the two native breeds of cow. Barłowska et al. (2006), evaluating selected technological parameters of the milk of cows of six breeds, showed the greatest increase in casein content in the milk of Polish Red cows (by 0.49 pp) and Simmentals (by $0.41 \mathrm{pp}$ ).

A significant indicator of the suitability of milk for cheese production is its rennet clotting time. The shorter coagulation time observed in our study in the cows raised on low-input farms, including local breeds, is confirmed in other studies (Bittante et al., 2012; De Marchi et al., 2007; Litwińczuk et al., 2012). Lengthening of rennet clotting time was confirmed by Varotto et al. (2015), who evaluated coagulability parameters of milk (RTC, i.e. the time of coagulation from the moment rennet is added, and $a_{30}$, defining the springiness of the clot 30 min after adding a clotting enzyme) during lactation in Rendena and Holstein-Friesian cows. The most beneficial parameters were noted in the milk at the beginning of lactation, and they began to deteriorate at mid-lactation.

Another important indicator in evaluating the suitability of milk for cheese production is milk fat dispersion. Fat globules are surrounded by a phospholipid membrane with strong ability to bind water. Goudédranche et al. (2000) demonstrated greater firmness of cheeses produced from milk with larger fat globules. The membranes of fat globules have the ability to bind $\beta$-lactoglobulin, which can increase cheese yield (Molina et al., 2000). Barłowska et al. (2014), evaluating the effect of the phase of lactation on milk fat dispersion in cows of four breeds raised in intensive farming systems, report that in the final phase the percentage of large fat globules $(\geq 10 \mu \mathrm{m})$ in the milk decreased.

To sum up, the cows of both native breeds raised on low-input farms, i.e. Polish Red and White-Backed, had inferior lactation persistency in comparison with the Simmental breed. However, the increase in fat and protein content, including casein, in their milk was markedly higher, while the increase in cholesterol was smaller. The percentage of large fat globules in milk decreased more clearly in the course of lactation of the native breeds of cows compared to Simmental and Polish Black-andWhite Holstein-Friesian cows.

\section{References}

A menu B., Deeth H.C. (2007). The impact of milk composition on cheddar cheese manufacture. Aust. J. Dairy Technol., 62: 171-184.

AOAC (2000 a). Official Methods of Analysis. Casein Nitrogen Content of Milk. 998.06. AOAC International, Chapter 32, 52. 
AOAC (2000 b). Official Methods of Analysis. Collection of Milk Laboratory Sample. 925.20. AOAC International, Chapter 33, 4.

AOAC (2000 c). Official Methods of Analysis. International. Method IDF-ISO-AOAC 905.02. Gravimetric method (Röse-Gottlieb).

B a r ło w s k a J., L i tw in c zu k Z., K ow a l M. (2014). Influence of production season and lactation stage on the technological suitability of milk from cows of various breeds fed in the TMR system. Ann. Anim. Sci., 14: 649-661.

B arłow sk a J., Litwín c zuk Z., K ról J., To pyła B. (2006). Technological usefulness of milk cows of six breeds maintained in Poland relative to a lactation phase. Pol. J. Food Nutr. Sci., 15/56: $17-21$.

B ittante G., Pen as a M., Cec chin ato A. (2012). Invited review: Genetics and modeling of milk coagulation properties. J. Dairy Sci., 95: 6843-6870.

Bouallegue M., M'hamdi N., Ben Hamouda M., Haddad B. (2014). Study of nongenetic factors on the shape of lactation curves for milk yield, fat and protein percents of HolsteinFriesian cows under hot Mediterranean climate. Archiva Zootechnica, 17: 55-75.

Cilek S., Orhan H., Kayg is iz A., Hesn a S a hin E. (2008). Estimation of breeding values of Anatolian population of Simmental cows using monthly test day milk yields. Archiva Zootechnica 11: 79-85.

Commission Regulation (EC) No 1662/2006 of 6 November 2006 amending Regulation (EC) No $853 / 2004$ of the European Parliament and of the Council laying down specific hygiene rules for food of animal origin.

D a vi e s D.T., W h i te J.C.D. (1966). The stability of milk protein to heat: I. Subjective measurement of heat stability of milk. J. Dairy Res., 33: 67-81.

De Marchi M., Dal Zotto R., Cassandro M., Bittante G. (2007). Milk coagulation ability of five dairy cattle breeds. J. Dairy Sci., 90: 3986-3992.

Goudédranche H., F a u quant J., M a u bo is J.L. (2000). Fractionation of globular milk fat by membrane microfiltration. Le Lait, 80: 93-98.

Gre g a T., S a d y M., N a j g e b a u e r D., D o m a g a ł a J., F a b e r B. (2005). Bioactive components of milk from different cow breeds. Biotechnol. Anim. Husb., 21: 35-38.

H e in s B.J., H a n s e n L.B., D e Vries A. (2012). Survival, lifetime production, and profitability of Normande $\times$ Holstein, Montbéliarde $\times$ Holstein, and Scandinavian Red $\times$ Holstein crossbreds versus pure Holsteins. J. Dairy Sci., 95: 1011-1021.

Hi emstra S.J., De Haas Y., Mäki-Tanila A., Gandini G. (2010). Local cattle breeds in Europe. Wageningen Academic Publishers, The Netherlands.

I k o nen T., Morri S., Tyr is e vä A.M., Ru ot tin en O., O j a la M. (2004). Genetic and phenotypic correlations between milk coagulation properties, milk production traits, somatic cell count, casein content, and pH of milk. J. Dairy Sci., 87: 458-467.

Joźwik A., Strzałkowska N., Bagnicka E., Grzybek W., Krzyżewski J., Poław s k a E., K oł a t a j A., Hor b a ń c z u k J.O. (2012). Relationship between milk yield, stage of lactation, and some blood serum metabolic parameters of dairy cows. Czech J. Anim. Sci., 57: 353-360.

K o n o p i ń s k i T. (1949). Cattle breeding (in Polish). Instytut Naukowo-Wydawniczy Ruchu Ludowego „Polska”. Poznań, Poland.

L itw iń c zu k Z. (2011). Editor. Conservation of genetic resources of livestock and wild animals (in Polish). Warsaw, Poland, PWRiL (2011), p. 294.

L it w iń c zu k Z., B a rłow s k a J., Cha bu z W., B rodziak A. (2012). The nutritional value and technological suitability of milk from cows of 3 Polish breeds included in the programme of genetic resources conservation. Ann. Anim. Sci., 12: 423-432.

L itw iń c zuk Z., Kowal M., B arłows k a J. (2014). Basic chemical composition, proportion of fatty acids, and cholesterol content in milk of four breeds of cows used in the intensive husbandry technologies (in Polish). Zywn. Nauk. Technol. Ja., 4: 108-121.

Litwińczuk Z., Barłowska J., Król J., Brodziak A., Matwijczuk A., Kowal M. (2015). Chemical composition and technological suitability of milk with regard to the feeding system of cows (in Polish). Med. Weter., 71:, 231-235.

Molina E., Álvarez M.D., Ramos M., Olano A., Lopez-Fandino R. (2000). Use of high-pressure-treated milk for the production of reduced-fat cheese. Int. Dairy J., 10: 467-475. 
N or N.M., S t e e n e v e ld W., H o g e v e e n H. (2014). The average culling rate of Dutch dairy herds over the years 2007 to 2010 and its association with herd reproduction, performance and health. J. Dairy Res., 81: 1-8.

Pijanowski E., Dłużewski M., Dłużewska A., Jarczyk A. (2000). All food technology (in Polish). Wydawnictwo Naukowo-Techniczne, Warszawa, Poland.

Prusk i W. (1975). Breeding of livestock animals in Galicia District in years 1772-1918 (in Polish). Zakład Narodowy im. Ossolińskich, Warsaw, Poland.

Sabbioni A., Beretti V., Tardini L., Vezzali S., Paini V., Superchi P. (2012). Milk production and lactation curves of Bianca Val Padana and Italian Friesian dairy cows in relation to the management system. Ital. J. Anim. Sci., 11: 140-144.

S a w a A., Kr ęż e l-C z o pek S., B o g u c ki M. (2015). Dry period length as related to milk yield and SCC during the first month of subsequent lactation. Ann. Anim. Sci., 15: 155-163.

Secchiari P., Mele M., Serra A., Buccioni A., Paoletti F., Antongiovanni M. (2003). Effect of breed, parity and stage of lactation on milk conjugated linoleic acid content in Italian Friesian and Reggiana cows. Ital. J. Anim. Sci., 2 (Suppl. 1): 269-271.

Sobotka W., Miciński J., Matusevičius P., S taniškienè B., Sobiech M., Zwierzchowski G., Fiedorowicz E., Pi etrzak-Fiećk o R. (2014). The effect of cattle breed and lactation stage on nutrient concentrations in milk and the fatty acid profile of milk fat. Vet. Med. Zoot., 65:, 85-90.

Strzałkow sk a N., Jóźw i k A., B a gn i cka E., Krzyżew s k i J., C oo per R. G., Horbań c z u k J. O. (2010). Factors affecting the cholesterol content of milk of cows fed conserved feeds in a TMR system throughout the year. Mljekarstvo, 60: 273-279.

To ga sh i K., Li in C.Y. (2009). Economic weights for genetic improvement of lactation persistency and milk yield. J. Dairy Sci, 92: 2915-2921.

To p ols ki P., Choros zy B., Choros z y Z. (2008). Effect of production level in Polish HolsteinFriesian cows of Black-and-White variety on lactation persistency and length of calving interval (in Polish). Rocz. Nauk. Zoot., 35: 93-99.

Varot to A., De Marchi M., P en a a M., Cas s andro M. (2015). A comparison of milk clotting characteristics and quality traits of Rendena and Holstein-Friesian cows. Ital. J. Anim. Sci., 14: $202-206$.

Z ann on i M. (2010). Evolution of the sensory characteristics of Parmigiano-Reggiano cheese to the present day. Food Qual. Prefer, 21: 901-905.

Received: 31 VIII 2015

Accepted: 12 I 2016 
